\title{
JUDICIAL LEGISLATIVE ESTOPPEL
}

\section{R. Mason Lisle, of the Pennsylvania Bar.}

Judicial legislative estoppel-stated broadly but with sufficie.it accuracy for the purpose of this paper-may be defined to be: The refusal of a court, by reason of its application of the doctrine of estoppel, to execute a constitutional legislative grant. This definition will be made clearer by an illustration: if a duly enacted constitutional law, expressly provides that a corporation shall no: change its fundamental charter provisions, under its power to alter and amend its charter, and, the corporation proceeds-notwithstanding this limited power of alteration-to enact an amendment to its cliarter which does change its fundamental provisions and then enters into a contract upon the basis of this illegal fundamental change; in such an event, no matter how the question comes before a court-if not in a collateral way,.when it is really not before the court at all-the court must declare the contract, which is in violation of the fundamental charter provisions, ultra irires $a b$ initio and illegal, not voidable but wholly void and of no legal effect, for, if the court permits the contract to stand, by reason of the conduct of any party to the contract, it is exercising a judicial legislative estoppel-a thing abhorrent; where the law is supreme. In other words, a court which permits an illegal contract to stand, by its application of an estoppel, is defeating the legislative intent, for the reason, that the court is, thereby, making itself superior to the legislature in the legislative sphere. Of course, a court should condemn an unconstitutional law, but it cannot take unto itself the authority to change a constitutional legislative grant, by an estoppel, for, if a court so proceeds, it is, thereby, necessarily, permitting a corporation to do what the legislature has said it shall not do and it is thus thrusting itself into a position of superiority to the legislature, as a law-maker.

One of our greatest dangers comes from the fact that our people are rapidly approaching a condition of unwillingness to be governed by the law-almost all our efforts are devoted to the discovery of some method by which we can escape the law, rather than evincing a devotion to the staunch maintenance of the unquestionably sound proposition: the law is supreme and no one is superior to it. In his recent address before the Bar Associations of Virginia and Maryland, Mr. Justice Lurton, practically 
took this subject as his theme. What he said is so thoroughly sound, we venture to quote from a newspaper clipping-assuming it to be correct, for, it has such a true ring and expresses so accurately the principle under which only our government can endure:

"Which shall it be," Mr. Justice Lurton said, "a government of law or a government of men? Is there not a growing disposition to disregard the limitations which we have placed upon those in authority and a tendency to applaud the doing of things which we wish done, regardless of whether lawful or unlawful? If one in power does things which displease us, we are swift to inquire into his authority, but is that so of the things done which meet with our approval? Our Government is properly a government of law. Our courts should simply exercise their judicial powers and no court should assume legislative power."

And, we add, following Mr. Justice Lurton's thought, it is not a government of law when a court exercises a judicial legislative estoppel, for, then, it becomes a government of men-of the judiciary-rather than of law.

Happily, the instances of this exercise of judicial legislative estoppel are not many, but when they have occurred, they are generally found to have been exercised in the cases of ultra vires and illegal corporate contracts. Whilst this error has been made in courts inferior to the United States Supreme Court and in the courts of various states, we add, with great pleasure, that the Stpreme Court of the United States has never made such a "slip." The question has come up in this latter court very many times, presented differently, and argued differently; but it will be recognized that, in the final analysis, the controlling and enduring factor, although not always so stated, because not directly developed in the argument, has been the impossibility of supporting a judicial legislative estoppel.

It is a well known rule of law-always followed in the Supreme Court of the United States, but not alwava followed in other courts-that, "the contract of a corporation, beyond the scope of its powers, cannot be enforced or rendered enforceable by the application of the doctrine of estoppel"; that is, an ultra vires ab initio corporate contract is not voidable, but it is wholly void and of no legal effect. The raison d'etre of this rule is founded upon this principle of law ; the judiciary exists for carrying out the law, hence, it can never, by estoppel, render naught a legitimate legislative intent, for, if it does, it becomes itself, like the corporation, 
guilty of a violation of law-it is exercising a judicial legislative estoppel-making law rather than interpreting it. This rule is unalterable, never to be departed from; there are no exceptions to it; it provides, not doubtfully, but clearly, that estoppel cannot apply if its effect is to sustain an ultra vires corporate contract; if estoppel is applied in such a case, it becomes-to repeat myself-a judicial legislative estoppel, and the court issuing it is, itself, guilty of taking part with the corporation in a violation of law, but, as an old-time English judge said: "A court cannot be made the handmaid of iniquity!" 1 The duty of the courtits whole duty-is contained in this statement: "Courts are instituted to carry out the laws. How can they become auxiliary to the consummation of their violation?"

This rule of law is as old as the law itself and the principle of law upon which it is founded had its origin in very early times, in the common law. But, really, it may be said to have always existed, for a principle of law is a truth and the sublime words of Milton tell us: "Truth is next to the Almighty," hence, a principle of law may be said, correctly, to have always existed. But this principle first appeared in law, in causes of actions, founded upon contracts contra bonos mores, and in speaking of this type, Mr. Justice Peckham said: " "It is stated that Lord Kenyon once said, by way of illustration, that he would not sit to take an account between two robbers in Hounslow Heath." Contracts involving bad morals, wherein the public is interested, have never been sustained by the courts-for courts exist, not to assist an iniquity, but to crush it. It was just this point which led Sir William Grant ${ }^{3}$-a - master mind in chancery-to say: "No matter who complains of it, it is illegal. You cannot take a step but through that illegal agreement and it is impossible for the courts to enforce it." Of course, when the public interests are not involved, that is, where the contract is not contra bonos mores, one cannot give in evidence one's own fraud in defense of one's own fraudulent acts, and the court, by estoppel, will decline to interfere, or, as once said by a judge in such a case: "The court will not help a rogue out of his toils."

It is really very clear, when and when not the court can exercise an estoppel :4 "When the public is not interested the maxim

1 Also quoted in Bank of the $U . S$. v. Owens, 2 Peters, 538.

2 McMullin v. Hoffman, 174 U. S., 654.

${ }^{8}$ Thompson v. Thompson, 7 Ves., 470.

- Appeal of Bredin, 92 Penna. St., 241. 
nemo allegans suam turpitudinem audiendus est is in full force and the law leaves the parties as they placed themselves and the authority of a long line of decisions prevents the abuse of this maxim"; but, where the public is interested, this maxim does not apply, for the reason that it is the court's province to execute the law-not to make it, and, hence the court must prevent the evil which would be produced by enforcing the contract or allowing it to stand. There is not the slightest possible doubt of the correctness of this last statement-unhappily, not always followed-and the only question is: when is the public interested in a contract? The public is interested: ( 1 ) when the contract is contra bonos mores, and (2) in the case of a corporation, when the contract is ultra vires of the corporate powers; that is, when the corporation proposes to do what the people in legislature assembled, has said it shall not do.

When corporations for profit came into existence, questions of contracts ultra vires-not of bad morals-but of corporate charters, soon arose. There was only one way in which the judiciary should have always considered these ultra zires contracts and that was in exactly the same way the earlier courts had dealt with contracts contra bonos mores. The analogy is exact and the Supreme Court of the United States has never failed to realize it-this we will show in a moment by citations from that court. A corporation-like the Government-is vested with limited, delegated powers by the people through legislative act, and, for it to exercise powers not granted nor necessarily implied, is to act outside the purpose of its existence-to give itself a power which is unconstitutional, and such an unconstitutional power can no more be supported by judicial legislative estoppel than can an unconstitutional act of Congress or of a State Legislature be sustained. In each case, the constitution is created by the people-the State Constitution, by the people directly; the Corporation Constitution by the people in their constitutionally elected Legislature assembled; the same principle of law which condemns an act of Congress or an act of the Legislature-violative of the Constitution, condemns an act of a Corporation-violative of its Constitution. The position of the judiciary, in reference to the National or State Constitution, and in reference to the Corporation Constitution, in a case of this kind, is identical: the court must enforce the lawwhether expressed by the people in a State Constitution, or by the people, through their Legislature, in a Corporate Constitution, and, if the judiciary fails to enforce the law, in either case, it is 
exercising a judicial legislative estoppel. The Supreme Court of the United States recognizes to its fullest extent that ultra vires and illegal corporate contracts are governed by the same rule, which, from the earliest times, has always been applied to contracts contra bonos mores and any impression that the rule is confined, solely, in the case of corporations, to contracts contra bonos mores, is distinctly negatived by Mr. Justice Gray:" "The contract of a corporation which is ultra vires in the proper sense, that is to say, not because it is in itself immoral, but because it is outside the objects of its creation, is not voidable, but wholly void and of no legal effect," and the principle of law, applicable to each type of case: (I) "contracts contra bonos mores, and (2) contracts ultra vircs of corporate powers, is the same, and it has been the guiding polar star in all the decisions in the Supreme Court upon this question.

It is quite impossible to cite from the Supreme Court of the United States all the authorities upon this question; but in order to maintain my position, I must burden this paper with some citations, and I feel confident that those who read these citations will be convinced that the Supreme Court is anchored-in splendid holding ground, but that those inferior courts and those State courts which, in some way or other, whilst recognizing the principle as applicable to contracts contra bonos mores, have failed to apply" the same principle to contracts ultra vires of corporate powers, are adrift 'way out at sea.

The Supreme Court has said:०

"No court of justice can be made the handmaid of iniquity. Courts are instituted to carry into effect the laws of the country. How can they become auxiliary to the consummation of violation of law? There can be no legal remedy for that which is itself illegal; in such cases [ultra vires corporate contracts] there can. be no waiver, the defense is allowed, not for the sake of the defendant [or, of any party to the contract], but of the law itself; whenever the illegality appears, whether the evidence comes from one side or the other, the disclosure is fatal to the case. No consent of the defendant can neutralize its effect. A stipulation in

${ }^{5}$ Central Transportation Co. v. Pullman Co., 139 U. S., 60.

${ }^{6}$ Bank of the U.S. v. Owens, 2 Peters, 38; Coppell v. Hall, 7 Wall., 558; Thomas v. Railroad, 101 U. S., 81-85; Penna. R. R. v. St. Louis $R$. R., 118 U. S., 316-317; Central Transportation Co. v. Pullman Co., 139 U. S., 55-60; Jacksonville Ry. v. Hooper, 160 U. S., 514; Union Pacific Ry. v. Chicago Ry., 163 U. S., 581; McCormick v. Market Nat. Bank, 165 U. S., 546. 
the most solemn form to waive the objection would be tainted with the vice of the original contract and void for the same reason. Where the contamination reaches, it destroys; an ultra vires clause is not voidable, but wholly void and of no legal effect; it cannot be enforced or rendered enforceable, by the application of the doctrine of estoppel; the ultra vires cannot be ratified by either party, no performance on either side can give the unlawful contract any validity or be the foundation of any right of action upon it; whether the act is ultra vires is a judicial question, to be settled and determined by the courts and judges, and if ultra vires, estoppel to support it, is totally inadmissible."

Mr. Justice White, in California Bank v. Kennedy, said: "Whatever divergence of opinion may arise in some of the State courts, in this court it is settled in favor of the right of a corporation to plead the want of power, that is to say, to assert the nullity of the act, which is an ultra vires act." This statement of the court, speaking through Mr. Justice White, is supplemental of the earlier statement of the court, speaking through Mr. Justice Miller, in Thomas $v$. Railroad, 8 and, considered together, they show what has always been the inexorable rule of that court. Mr. Justice Miller said: "Where a corporation, a party to a continuing contract, which it had no power to make, seeks to retract and refuses to proceed further, it cannot [by estoppel] be compelled to continue the contract; having entered into an ultra zires contract, it was the duty of the company to rescind or abandon it at the earliest moment, and it is a rightful act when this is done, for it is the performance of a legal duty." I must be pardoned one more quotation. In O'Brien v. Wheelock, the act under consideration was unconstitutional and Mr. Chief Justice Fuller said:

"The court is asked to execute the act, either as in itself wholly valid, or valid as to these defendants. We are unwilling to assent to the doctrine of legislative estoppel (the italics are mine). The courts cannot, by the execution of an unconstitutional law, as a law, supply the want of power in the legislative department. ${ }^{10}$ In South Carolina v. Perkins,", it is said: "There can be no estoppel

7167 U. S., 367.

8101 U. S., 81-85.

- 184 U. S., 489.

${ }^{10}$ And, in the case of corporations, the court cannot, by the execution of an unconstitutional corporation law-unconstitutional in the sense of ulira vires of the corporate powers granted by the legislature-as a law, supply the want of power in the corporate constitution to enact the said law. This, also, is judicial legislative estoppel.

1194 U. S., 267. 
in the way of ascertaining the existence of a law. That which purports to be a law of a State is a law or it is not a law, according as the truth of the fact may be and not in accordance to the shifting circumstances of the parties. It would be an intolerable state of things, if a document, purporting to be an act of the legislature could thtis be a law in one case and for one party and not a law in another case and for another party; a law to-day and not a law to-morrow; a law in one place and not a law in another place in the same State. And whether it is a law or not a law is a judicial question to be settled and determined by the courts and judges. The doctrine of estoppel is totally inadmissible in such cases." "'

Thus, it is perfectly apparent that the Supreme Court stands ever ready, firm as a rock, to condemn the assumption of legislative functions by the judiciary-all the fine traditions of that court and its decisions, foundecl, as we have shown, upon the true principle of law, present an impregnable position upon this question, which cannot be successfully assailed-no matter how skillful or how subtle may be the attack. Unhappily, however, in other and inferior courts, wherein the jurisdiction is final, and in some of the State courts, wherein there is no right of appeal to the Supreme Court of the United States, there have been frequent instances of the making of judge-made law by means of judicial legislative estoppel. The seriousness of this is quite beyond calculation. In America, to-day, there is hardly any one thing which has contributed more to the present uneasiness and discontent than the almost universal feeling that corporations are not subordinate to the law-made so apparent to all by the case with which they escape obedience to it. It is almost citing a platitude to state that we cannot continue to exist, unless the law remains supreme, and whenever judge-made law, in a judicial legislative estoppel, is announced, a dagger is driven, up to its hilt, in the body politic, ultimately leading-because other like thrusts will surely be made - to its dissolution. Our country is so large and so charged with wealth, and the ramifications of its varied interests are so complex, that the influence of one judicial legislative estoppel or judge-made law is, of course, almost imperceptible; but if, in the future, our decadence overwhelms us, I take it, the scientific historian will conclude, that, in no small degree, it owed its originthe germ of it, as it were-to the contempt for the supremacy of the law-a contempt thrust upon our people, as a natural and rational consequence of the ease with which corporations place themselves outside of the law. It is perfectly clear that judge- 
made law or judicial legislative estopped has a two-fold effect upon us all; in each aspect it is very bad: (I) It creates a doubt as to whether we are really governed by the law, and (2) we all know the consequences of familiarity, as expressed in the homely maxim, and this maxim holds true in this case: It is the inevitable consequence of the frequent violation of law, that a widespread contempt for the administration of the law is gaining ground in our country; if corporations are not kept to the law; why should we be, say the people? Thus, the bacillus of contempt is given a wonderfully productive feeding ground.

$\mathrm{Oh}$, that all these cases, wherein a judicial legislative estoppel has been maintained, could, upon final appeal, have reached the Supreme Court of the United States! But that could not be, and hence, the purpose of this paper is to make it clear, that whenever this error has been made, it is not the fault of the law, but of those who have administered it. And it behooves our courts throughout the land, for the sake of the national welfare, to be ever astute to see that they clo not, perhaps by reason of some side issue, which befogs the true issue, fall into the error of announcing a judicial legislative estopped, thereby constituting themselves makers of the law rather than interpreters of it. Better ten thousand corporations should be kept within the law, rather than a contempt for it should gain one recruit, for, upon such a question, one recruit means many.

Not for one moment do I mean to imply, where a juclicial legislative estoppel has been announced, that the court, making the decision, has been guilty of a wilful breach of trust. Whilst it is true that the great mass of the people may so think,and just here is the danger,-we lawyers know, very confidently, that this is very seldom the case. It is generally a pure legal "slip"-a most unfortunate one, it is true, for its consequences are direful, in tending to create a contempt for the law. It would, incleed, be lamentable, if the deliberate purpose of such errors had been to accomplish that which, I have shown, a juclicial legislative estoppel must, inevitably, accomplish-judge-made law. To maintain this wotld be to hold corrupt the judiciary who have so decided, and this I am unwilling to do, because I do not believe it. Then, how is it that this error has been so often made? It will be recalled that I referred to this error as a judicial "slip." Now, the synonymous words of "slip" are: "mistake," "blunder," "oversight," and we think that these latter words accurately de- 
scribe, in almost all cases, just what has taken place when court has sustained an ultra vires contract. The court has $r$ for one moment realized that it was announcing a judicial legis. tive estoppel一a positive enormity under our laws-making itse superior to the law-making power. Of course, it is understood $u$ use the words ultra. vires in their proper sense, that is, ultra vire not in the sense of a mere lack of power; but ultra vires in th sense of illegal, something that is unlawful, contra bonos more: or directly prohibited by the legislative grant. It seems that th. error-"blunder," "mistake," or "oversight"-has occurred $i$ some such way as this: A party to a continuing corporate con. tract, containing one ultra vires provision, has attempted to hav: that one clause declared ultra vires, illegal and of no effect in law, whilst wishing to continue in force all the remainder of the contract; or, to state it in another way, to claim the benefits of the contract whilst repudiating the burdens of the ultra vires clause. In a case of this character, a court, without very great care, could become mentally impregnated, obsessed with the thought of the apparent injustice to the corporation, of permitting the other party to the contract to repudiate the ultra vires clause and yet to retain the benefits of all of the rest of the contract; we repeat, this apparent injustice could so easily take possession of the judicial mind-save the very clearest; it has never influenced the Supreme Court-that it would not appreciate-the fact that in permitting the ultra vires to stand, it had necessarily exercised-a judicial legislative estoppel.

In cases of the above type, a court could almost logically be led astray by reasoning somewhat in this way:

"The minds of the parties met in this contract, and agreed to be bound by its terms; one of these terms, thus agreed to, was the right of the company to enforce a certain clause, which is ultra vires and illegal. When the company proceeds to enforce this clause, in this properly executed contract, the court, of course-so the reasoning proceeds-will not entertain the plea of the other party to the contract, that the said clause is ultra vires, illegal and of no effect in law, at the same time maintaining that the remainder of the contract is still in force. The court will not for one moment consider this plea, because it presents an entirely different contract from the one made by the parties-hence, the minds of the parties never met in this new contract, and the company has never agreed to it; if the court were to so proceed it would be upholding the making of a contract by one party to it, to bind both parties. Of course, this cannot be done. No! if the party stands upon the contract, he must stand upon it as an 
entirety, even though some of its provisions are ultra vircs and illegal of the corporate powers; but he wishes the court to maintain the contract in force, whilst declaring the ultra vires clause illegal and of no effect in law. This we will not do and we dismiss the bill, leaving the parties as they placed themselves, and, thus, we permit the entire contract to stand-including the ultra vires clause."

Now, this reasoning is absolutely sound-looking at the contract as a contract, per se, between the parties, and it is not difficult to understand how the judicial mind might be shunted from the true issue. The error of it all, however, is not obscure, and the "mistake," "oversight," or "blunder," is, in the failure to recognize the fact that such a contract cannot be regarded solely as a contract between the corporation and the other contracting party, wherein the conduct of the latter can be controlled by an estoppel, and the parties left as they placed themselves, for it utterly overlooks the fact that the ultra vires provision was illegal -it was something the legislature has said could not be made.

We have already stated the principle of law, controlling the application of an estoppel, and we here repeat it: when the public is not interested the maxim nemo allegans suam turpitudinem audiendus est, is in full force; but, when the public is interested, the maxim does not apply and it is a positive fact that the public is interested, equally, when the contract is: (I) contra bonos mores, or (2), in a corporate contract, when it is ultra vires of the corporate powers; in both of these cases, the court cannot, by an estoppel, leave the parties as they have placed themselves. It is perfectly evident, in both of these cases, that it is of no importance what the parties may have done. The Supreme Court of the United States has said repeatedly: "It is of no importance from which side the evidence of the ultra vires comes, the disclosure of it is vital; no agreement to waive the ultra vires can neutralize its effect; it cannot be ratified, because it cannot be authorized by either party and no performance on either side can give the unlawful ultra vires any validity, and, as we have said before, the raison d'etre of all this is: if the court permits the ultra vires to stand, it is a judicial legislative estoppel, and the court is assisting the corporation in doing exactly what the legislature has said it shall not do.

Now, if the courts in these ultra vires cases had decided that the ultra vires clause destroyed the entire contract, their decisions would have been perfectly sound; but they reached their conclu- 
sions-erroneous, unquestionably-from a feeling upon their part, so strong that it has blurred their judicial acumen, that they must maintain the integrity of the freedom of contract, and, as these contracts were, per se, legal contracts, properly executed, etc., etc., they have supported them in their entirety, overlooking the fact that a clause in the contract is illegal-something that was utterly out of the power of the corporation or the other contracting party to agree to, and, furthermore, completely overlooking the fact, that the maintenance of the contract was a matter of no consequence at all, in comparison with that which should have been of the greatest paramount importance to the courtits not taking any part in assisting in the violation of the law. These courts should have struck down the ultra vires clause in any and in every event, maintaining that this did or did not destroy the entire contract, according, as they found this ultra vires clause to be or not to be a fundamental part of the whole contract, dependent upon the consideration-a question involving the law of contracts; that is, as explained in U.S. v. Hudson, ${ }^{12}$ whether the ultra vires clause was severable from the other provisions or whether all the provisions were a unit. But, let the consequences be what they may to the rest of the contract, an ultra vires clause should always be declared illegal and void-and thereby, a court will be saved from falling into the trap of maintaining a judicial legislative estoppel ; unfortunately, the effect of such an estoppel and its influence is quite the same, even if the "slip" is only a "mistake," or "blunder," or an "oversight."

I would that this paper could be read by every judge in the land, for it is incumbent upon them all to see that a judicial legislative estoppel does not "slip" through their courts. No matter for what reason the estoppel may issue, its effect must be to override the will of the people as expressed in their legislature assembled. It is bad, irredeemably bad, and, as Mr. Justice Lurton said in the address referred to, "courts should simply exercise their judicial powers, and no court should assume legislative powers." As this statement is founded upon the true principle of law, it is equally applicable to every court in the land-under no possible circumstance should any court ever maintain a judicial legislative estoppel.

It is well that we should all realize-the judiciary, the lawyer and the layman-just what a judicial legislative estoppel means. And, first (I), as to the corporation, it means: "No matter how

\footnotetext{
1210 Wall., 395.
} 
JUDICIAL LEGISLATIVE ESTOPPEL

I 2 I

limited the designs and powers of a corporation may appear in its charter, practically, it is a corporation without limitations as to its powers," and it means, also, "that a corporation, no matter how limited its powers, may make itself omnipotent. It has only to induce persons to contract with it beyond the scope of its powers and its very usurpation has the effect of conferring powers on it which the legislature has withheld." A proposition more absurd can scarcely be imagined. That is, the court, by its legislative estoppel, has made the corporation superior to its creator -the people in legislature assembled; and, secondly (2), as to the judiciary, it means, that the judiciary has taken unto itself a higher legislative power than the people themselves, from whom, of course, all laws emanate; for by its estoppel, the pudiciary permits that to be done which the people-speaking through their legislature-have said cannot be done. Can one conceive of anything much worse? And the pity of it is, this error has generally been made through a judicial "slip."

I beg to add, all that I have said applies equally to that which I might call-executive legislative estoppel and executive judicial estoppel, and, also to, legislative executive estoppel and legislatire judicial stopped. Our Government is a government of law, consisting of three coordinate branches; let them each be proserved in their integrity, else we will surely reap the whirlwind and deserve it, too. Why is it, that these co-ordinate and coequal branches do, from time to time, make thoughtless excursions into each other's sphere of authority? The greatest respect for the law is attained by complying with it.

R. Mason Lisle. 